\title{
A Model Analysis of Industrial Specialization for Innovation Intensive Service: Case of Telematics Service Industry
}

\author{
Chia-Han Yang \\ Institute of Management of Technology, National Chiao Tung University \\ Hsinchu, Taiwan, ROC \\ Jou-Chen Chen \\ Institute of Education, National Chiao Tung University \\ Hsinchu, Taiwan, ROC \\ Joseph Z. Shyu \\ Institute of Management of Technology, National Chiao Tung University \\ Hsinchu, Taiwan, ROC
}

\begin{abstract}
This research focuses on analyzing the specialization models of service industry. Particularly, a correlation between innovation types and specialization strategies will be constructed for the analysis of industrial specialization enabled by the IIS (innovation intensive service) platform model. A case study of Taiwan's Telematics service industry is also used in this research to demonstrate the validity of this specialization model. The IIS platform framework depicts the inter-linkages among six innovation types and eight specialization strategies in accordance with the requirements of value activities and externalities. This model connects firm's core competence, value activities, externalities, and specialization strategy, allowing analysis of needed integration of value activities and externalities based on pre-determined specialization strategy. Results of the empirical study reveal that the optimal specialization strategies of Taiwan's Telematics service industry is the marketing brand \& channels specialization based on market innovation, and the network \& platform operations specialization based on structural innovation.
\end{abstract}

\section{INTRODUCTION}

With knowledge dynamically evolving and globally proliferating, new value has be created in global industries under the knowledge-based economy, and make the exploitation and utilization of knowledge play the predominant role in the value creation process. Several factors of industrial development are defined as driving forces of knowledge-based evolution such as diversity of highly segmented markets, systems and platform services, network effect derived from internet, and technology-enabled new markets (Evans \& Wurster, 1999, Chen, 2006) [1, 2]. Thus, the industrial situation under this stage is transformed into customer-centric leadership and knowledge intensive competition due to the reconfiguration of product commoditization. According to the theory of VCE (value chain evolution) (Christensen and Raynor, 2003) [3], in this stage, high-profit segments of value chain may move into the interfaces of industrial supply chain or process integration segments (Slywotzky, 1996) [4]. The trend provides considerable opportunities for small service or knowledge enterprises to develop innovation intensive services (IIS) based on the platform strategy and network externality. The size of these corporations with the nature of speed, flexibility and efficiency may be out of proportion to their leveraged capability enabled by expandable core competences; however, it can be just proper to prevail in the increasing return industry of this knowledge-based era (Arthur, 1996, Shapiro and Varian, 1999) $[5,6]$.

This research adopts the analytical model of innovation intensive service (Chen and Shyu, 2004) [7] based on the definition of conventional knowledge-intensive business services (KIBS) to explain the operation of services platform for developing specialization strategies. By means of this model, we construct a specialization analytical matrix that depicts the inter-linkages among six innovation types and eight specialization strategies. Starting from customized services, this institutional framework will enable a contextual understanding of the transition from different innovation types into different industrial specialization, and provide a guideline allowing strategic resource allocation for industrial specialization. An empirical case of Taiwan's Telematics service industry is also used in this research to demonstrate the validity of this specialization model.

\section{DEFINITION OF KIBS}

In the last several decades there has been a tremendous wave of interest in the research of knowledge-intensive business services (KIBS) due to the rapidly growth rate of business services, and a number of varying definitions have emerged to describe the scope of business services in the knowledge-based economy. Firstly, OECD (1999) [8] defines that KIBS includes transportation, communication, financing and insurance services. Miles et al (1995) addressed two types of KIBS firms, including traditional professional services and new technology based KIBS (T-KIBS). In addition, KIBS industries are also known as the private companies or organizations relying heavily on professional knowledge (Hertog and Bilderbeek, 1998) [9], and described as firms 
performing high intellectual value-added services, mainly for other firms (Muller, 2001) [10].

Chen (2006) [2] summarized the related discussion in the last few decades (Browning and Singelmann, 1975, Miles, 1995) $[11,12]$ to construct a categorization of KIBS, including peripheral \& supporting, innovation-intensive services (IIS), and professional services, as illustrated in Fig. 1. This research adopts the definition of IIS among this categorization to focus on analyzing the critical linkages between specialization strategies of manufacturing and service industries.

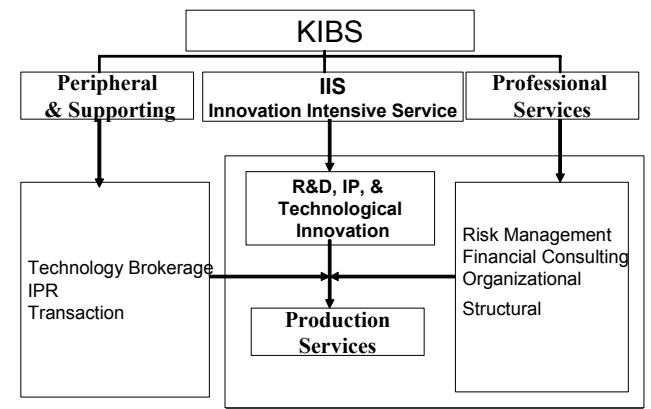

Fig. 1. Categorization of KIBS

\section{MODEL OF IIS PLATFORM}

This section focuses on explaining the structure of IIS platform proposed by Chen and Shyu (2004) [7]. This model is the essential framework to operate and syndicate the specialization strategies discussed in this research. IIS platform, a branch of KIBS, is an effective means bridging the interface between product and markets. It includes innovation activities of R\&D, intellectual properties management, technological innovation, and product services. Fig. 2. depicts the structure of the firm-level IIS model. This platform structure integrates the platform strategy, service package and network concepts to diffuse innovation. Core competence is the source of competitive advantages in every service firm and various innovation positions (Prahalad and Hamel, 1990) [13]. In accordance with this concept, innovation strategy could be separated into five categories: product, process, market, organization and structure (Hauknes and Hales, 1998) [14] as shown in Fig. 2. In the operation of this platform, service firms share and externalize their core competence to serve different types of customers through service process, which require network interaction of externalities, including complementary asset supplier, R\&D, technology, production, servicing, market and other users (Kash and Rycoft, 2000) [15], presented graphically in Fig. 2.

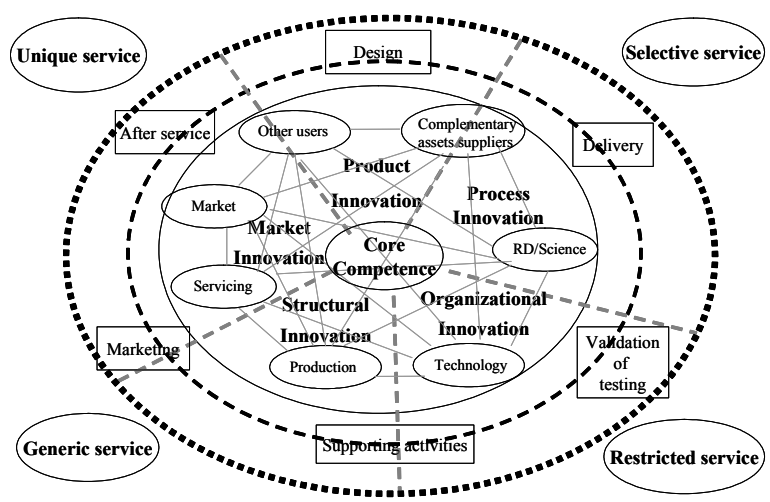

Fig. 2. Structure of IIS model

This IIS model also adopts the concept of system service interface (SSI) to illustrate how a service firm uses internal activities to spread its core competence to customers. SSI, the chain of operational activities to integrate innovation strategies into service value activities, is the link between core competence and customer activities. In this model, it introduces six service value activities of core competence, as depicted in Fig. 2: design, validation of testing, marketing, delivery, after service and supporting activities (Alam and Perry, 2002) [16]. After the integration of value activities of internal core competence and externalities, service package will be created in accordance with the classification of customer segments. Fitzsimmons and Fitzsimmons (1994) [17] offered a definition of the service package that consists of four features: supporting facility, facilitating goods, explicit services and implicit services. In addition, the service package also contains both tangible and intangible features as defined by Kellogg and Nie (1995) [18]. Thus, with these features, this model defines the service package by the degree of customization and divides into four categories, as illustrated in Fig. 2: unique, selective, restricted and genetic.

\section{SPECIALIZATION ANALYTICAL MATRIX}

This research assembles the innovation types and specialization strategies in the above discussion to devise a specialization analytical matrix (as shown in TABLE II). There are 48 segments in the analytical matrix by the combinations of 6 innovation types and 8 specialization strategies, and each segment represents one of possible paths in industrial specialization development. The managerial explanation means that the service enterprises could develop specific specialization based on the distinct innovation types.

The categorization of value activities and externalities summarized by the above IIS model in Fig. 2, will be used to describe the firm-level platform operation for achieving the corresponding specialization in each segment of the matrix. TABLE I presents seven externalities (expressed from E1 to E7) 
(Kash and Rycoft, 2000) [15] and six value activities (expressed from C1 to C6) (Alam and Perry, 2002) [16] defined in the IIS model. These firm-level elements (C and E) will be distributed into the 48 segments of matrix by the expert questionnaire investigation in this research, to clarify the firm-level requirements of platform operations for each specialization strategy. The method of expert questionnaire is adopted in this study to evaluate the significance of value activities (C) or 7 externalities (E) in each segment, thereby determining the importance of these requirements in the 48 industrial positioning. A group of 30 general managers and industry analyzers in research institutions or high-tech ICT enterprises from Hsinchu Science Park in Taiwan are asked from Sep. to Nov. in 2006, to evaluate the influences of each C and $\mathrm{E}$ for all 48 segments of matrix on a one-to-five rating scale.
Next, the statistical method of Chi-Square testing is also used to verify the consistency and significance of experts' answers in each question (selecting $\mathrm{p}$-value $<0.05$ ).

TABLE I

EXTERNALITIES \& VALUE ACTIVITIES

\begin{tabular}{c|c|c|c}
\hline & Externalities & \multicolumn{2}{c}{ Value Activities } \\
\hline \hline E1 & $\begin{array}{c}\text { Complementary assets } \\
\text { suppliers }\end{array}$ & $\mathrm{C} 1$ & Design \\
\hline E2 & R\&D & $\mathrm{C} 2$ & Validation of testing \\
\hline E3 & Technology & $\mathrm{C} 3$ & Marketing \\
\hline E4 & Production & $\mathrm{C} 4$ & Delivery \\
\hdashline E5 & Servicing & C5 & After service \\
\hline E6 & Market & C6 & Supporting activities \\
\hline E7 & Other users & & \\
\hline
\end{tabular}

TABLE II

ANALYSIS OF SPECIAIZATION ANALYTICAL MATRIX

\begin{tabular}{|c|c|c|c|c|c|c|c|c|c|c|c|c|c|c|c|c|}
\hline Innovation & $\begin{array}{r}\text { R\&D \& } \\
\text { Inno } \\
\text { Specia }\end{array}$ & $\begin{array}{l}\text { Product } \\
\text { ation } \\
\text { zation }\end{array}$ & $\begin{array}{r}\text { Mar } \\
\text { Bra } \\
\text { Cha } \\
\text { Specia }\end{array}$ & $\begin{array}{l}\text { ting } \\
\text { d \& } \\
\text { nels } \\
\text { zation }\end{array}$ & $\begin{array}{r}\text { M } \\
\text { Div } \\
\text { Speci }\end{array}$ & $\begin{array}{l}\text { ket } \\
\text { sity } \\
\text { zation }\end{array}$ & $\begin{array}{l}\text { Systen } \\
\text { Manuf } \\
\text { Speci }\end{array}$ & $\begin{array}{l}\text { Design } \\
\text { cturing } \\
\text { zation }\end{array}$ & $\begin{array}{r}\text { Reg } \\
\text { Clus } \\
\text { Speci }\end{array}$ & $\begin{array}{l}\text { onal } \\
\text { ring } \\
\text { zation }\end{array}$ & $\begin{array}{r}\text { Tech } \\
\text { Inno } \\
\text { Speci }\end{array}$ & $\begin{array}{l}\text { ology } \\
\text { ation } \\
\text { zation }\end{array}$ & $\begin{array}{l}\text { Fin } \\
\text { Stren } \\
\text { Inve } \\
\text { Por } \\
\text { Specis }\end{array}$ & $\begin{array}{l}\text { cial } \\
\text { hs \& } \\
\text { ment } \\
\text { olio } \\
\text { zation }\end{array}$ & $\begin{array}{r}\text { Netv } \\
\text { Pla } \\
\text { Ope } \\
\text { Speci }\end{array}$ & $\begin{array}{l}\text { rk \& } \\
\text { orm } \\
\text { tions } \\
\text { zation }\end{array}$ \\
\hline Product innovation & $\begin{array}{l}\mathrm{C} 1, \mathrm{C} 2 \\
\mathrm{C} 3, \mathrm{C} 6\end{array}$ & $\begin{array}{l}\text { E1, E2 } \\
\text { E4, E6 }\end{array}$ & $\begin{array}{c}\mathrm{C} 1, \mathrm{C} 3 \\
\mathrm{C} 4, \mathrm{C} 5 \\
\mathrm{C} 6 \\
\end{array}$ & $\begin{array}{l}\text { E1, E2 } \\
\text { E3, E4 } \\
\text { E5, E6 }\end{array}$ & $\begin{array}{c}\mathrm{C} 1, \mathrm{C} 3 \\
\mathrm{C} 5\end{array}$ & $\begin{array}{c}\text { E1, E4 } \\
\text { E5, E6 } \\
\text { E7 } \\
\end{array}$ & $\begin{array}{c}\mathrm{C} 1, \mathrm{C} 2 \\
\mathrm{C} 6\end{array}$ & $\begin{array}{l}\text { E1, E3 } \\
\text { E4, E6 }\end{array}$ & $\begin{array}{l}\mathrm{C} 2, \mathrm{C} 3 \\
\mathrm{C} 4, \mathrm{C} 5\end{array}$ & $\begin{array}{c}\text { E1, E3 } \\
\text { E4, E5 } \\
\text { E6 }\end{array}$ & $\begin{array}{l}\mathrm{C} 1, \mathrm{C} 2 \\
\mathrm{C} 3, \mathrm{C} 5\end{array}$ & $\begin{array}{c}\text { E1, E2 } \\
\text { E3, E4 } \\
\text { E5 }\end{array}$ & $\begin{array}{c}\mathrm{C} 1, \mathrm{C} 3 \\
\mathrm{C} 4, \mathrm{C} 5 \\
\mathrm{C} 6 \\
\end{array}$ & $\begin{array}{c}\text { E1, E2 } \\
\text { E5 }\end{array}$ & $\begin{array}{l}\mathrm{C} 1, \mathrm{C} 2 \\
\mathrm{C} 3, \mathrm{C} 6\end{array}$ & $\begin{array}{c}\mathrm{E} 2, \mathrm{E} 3 \\
\mathrm{E} 4\end{array}$ \\
\hline Process innovation & $\begin{array}{l}\mathrm{C} 1, \mathrm{C} 3 \\
\mathrm{C} 4, \mathrm{C} 5\end{array}$ & $\begin{array}{l}\text { E1, E2 } \\
\text { E3, E6 }\end{array}$ & $\begin{array}{c}\mathrm{C} 1, \mathrm{C} 2 \\
\mathrm{C} 3\end{array}$ & $\begin{array}{l}\text { E2, E3 } \\
\text { E5, E6 }\end{array}$ & $\begin{array}{c}\mathrm{C} 1, \mathrm{C} 2 \\
\mathrm{C} 3\end{array}$ & $\begin{array}{c}\text { E3, E5 } \\
\text { E6 }\end{array}$ & $\begin{array}{l}\mathrm{C} 1, \mathrm{C} 2 \\
\mathrm{C} 5, \mathrm{C} 6\end{array}$ & $\begin{array}{c}\text { E1, E2 } \\
\text { E3, E4 } \\
\text { E5 }\end{array}$ & $\mathrm{C} 1, \mathrm{C} 4$ & $\begin{array}{c}\text { E1, E3 } \\
\text { E5 }\end{array}$ & $\mathrm{C} 1, \mathrm{C} 3$ & $\begin{array}{c}\text { E1, E2 } \\
\text { E3, E5 } \\
\text { E6 }\end{array}$ & $\begin{array}{c}\mathrm{C} 3, \mathrm{C} 4 \\
\mathrm{C} 6\end{array}$ & $\begin{array}{c}\text { E3, E5 } \\
\text { E6 }\end{array}$ & $\begin{array}{l}\mathrm{C} 1, \mathrm{C} 3 \\
\mathrm{C} 4, \mathrm{C} 6\end{array}$ & E1, E5 \\
\hline $\begin{array}{c}\text { Organizational } \\
\text { innovation }\end{array}$ & $\begin{array}{l}\mathrm{C} 1, \mathrm{C} 2 \\
\mathrm{C} 5, \mathrm{C} 6\end{array}$ & $\begin{array}{l}\text { E1, E3 } \\
\text { E4, E6 }\end{array}$ & $\begin{array}{l}\mathrm{C} 1, \mathrm{C} 4 \\
\mathrm{C} 5, \mathrm{C} 6\end{array}$ & E3, E6 & $\begin{array}{c}\mathrm{C} 1, \mathrm{C} 3 \\
\mathrm{C} 4\end{array}$ & $\begin{array}{c}\text { E1, E3 } \\
\text { E5 }\end{array}$ & $\begin{array}{l}\mathrm{C} 1, \mathrm{C} 2 \\
\mathrm{C} 5, \mathrm{C} 6\end{array}$ & $\begin{array}{l}\text { E1, E2 } \\
\text { E3, E4 }\end{array}$ & $\begin{array}{c}\mathrm{C} 1, \mathrm{C} 4 \\
\mathrm{C} 6\end{array}$ & $\begin{array}{l}\text { E1, E3 } \\
\text { E4, E6 }\end{array}$ & $\begin{array}{l}\mathrm{C} 1, \mathrm{C} 3 \\
\mathrm{C} 5, \mathrm{C} 6\end{array}$ & $\begin{array}{l}\text { E1, E2 } \\
\text { E3, E4 } \\
\text { E5, E6 }\end{array}$ & $\mathrm{C} 3, \mathrm{C} 4$ & E3, E5 & $\begin{array}{c}\mathrm{C} 1, \mathrm{C} 3 \\
\mathrm{C} 5\end{array}$ & $\begin{array}{c}\text { E1, E5 } \\
\text { E6 }\end{array}$ \\
\hline $\begin{array}{l}\text { Structural } \\
\text { innovation }\end{array}$ & $\begin{array}{l}\mathrm{C} 1, \mathrm{C} 4 \\
\mathrm{C} 5, \mathrm{C} 6\end{array}$ & $\begin{array}{l}\mathrm{E} 2, \mathrm{E} 3 \\
\mathrm{E} 4, \mathrm{E} 6\end{array}$ & $\mathrm{C} 3, \mathrm{C} 5$ & $\begin{array}{l}\text { E1, E2 } \\
\text { E6, E7 }\end{array}$ & $\begin{array}{l}\mathrm{C} 1, \mathrm{C} 3 \\
\mathrm{C} 4, \mathrm{C} 5\end{array}$ & $\begin{array}{l}\text { E1, E3 } \\
\text { E4, E5 } \\
\text { E6, E7 }\end{array}$ & $\begin{array}{c}\mathrm{C} 1, \mathrm{C} 5 \\
\mathrm{C} 6\end{array}$ & $\begin{array}{c}\text { E2, E3 } \\
\text { E4, E5 } \\
\text { E6 }\end{array}$ & $\begin{array}{c}\mathrm{C} 1, \mathrm{C} 3 \\
\mathrm{C} 4\end{array}$ & $\begin{array}{c}\text { E1, E3 } \\
\text { E4, E5 } \\
\text { E6 }\end{array}$ & $\mathrm{C} 1, \mathrm{C} 6$ & $\begin{array}{c}\text { E1, E2 } \\
\text { E3, E4 } \\
\text { E5 }\end{array}$ & $\begin{array}{c}\mathrm{C} 2, \mathrm{C} 3 \\
\mathrm{C} 4, \mathrm{C} 5 \\
\mathrm{C} 6\end{array}$ & $\begin{array}{l}\text { E1, E2 } \\
\text { E6, E7 }\end{array}$ & $\begin{array}{l}\mathrm{C} 3, \mathrm{C} 4 \\
\mathrm{C} 5, \mathrm{C} 6\end{array}$ & E1, E5 \\
\hline Market innovation & $\begin{array}{l}\mathrm{C} 1, \mathrm{C} 3 \\
\mathrm{C} 5, \mathrm{C} 6\end{array}$ & $\begin{array}{c}\text { E1, E2 } \\
\text { E4, E5 } \\
\text { E6 }\end{array}$ & $\begin{array}{c}\mathrm{C} 2, \mathrm{C} 4 \\
\mathrm{C} 6\end{array}$ & $\mathrm{E} 4, \mathrm{E} 5$ & $\begin{array}{c}\mathrm{C} 2, \mathrm{C} 3 \\
\mathrm{C} 4, \mathrm{C} 5 \\
\mathrm{C} 6\end{array}$ & $\begin{array}{c}\text { E1, E4 } \\
\text { E5, E6 } \\
\text { E7 }\end{array}$ & $\begin{array}{c}\mathrm{C} 1, \mathrm{C} 2 \\
\mathrm{C} 4, \mathrm{C} 5 \\
\mathrm{C} 6\end{array}$ & $\begin{array}{l}\text { E1, E2 } \\
\text { E3, E4 } \\
\text { E5, E6 }\end{array}$ & $\begin{array}{l}\mathrm{C} 1, \mathrm{C} 2 \\
\mathrm{C} 3, \mathrm{C} 4 \\
\mathrm{C} 5, \mathrm{C} 6\end{array}$ & $\begin{array}{l}\text { E1, E2 } \\
\text { E3, E4 } \\
\text { E5, E6 }\end{array}$ & $\begin{array}{l}\mathrm{C} 1, \mathrm{C} 3 \\
\mathrm{C} 4, \mathrm{C} 6\end{array}$ & $\begin{array}{l}\text { E1, E2 } \\
\text { E3, E5 }\end{array}$ & $\mathrm{C} 3, \mathrm{C} 5$ & $\begin{array}{c}\text { E1, E3 } \\
\text { E5, E6 } \\
\text { E7 }\end{array}$ & $\begin{array}{c}\mathrm{C} 1, \mathrm{C} 3 \\
\mathrm{C} 4, \mathrm{C} 5 \\
\mathrm{C} 6\end{array}$ & E3, E6 \\
\hline $\begin{array}{l}\text { R\&D Investment } \\
\text { innovation }\end{array}$ & $\mathrm{C} 1, \mathrm{C} 6$ & $\begin{array}{l}\text { E1, E2 } \\
\text { E3, E5 }\end{array}$ & $\begin{array}{c}\mathrm{C} 2, \mathrm{C} 4 \\
\mathrm{C} 6\end{array}$ & $\begin{array}{l}\text { E2, E3 } \\
\text { E4, E5 } \\
\text { E6, E7 }\end{array}$ & $\mathrm{C} 1, \mathrm{C} 3$ & $\begin{array}{c}\text { E1, E2 } \\
\text { E4, E6 } \\
\text { E7 }\end{array}$ & $\begin{array}{l}\mathrm{C} 1, \mathrm{C} 2 \\
\mathrm{C} 4, \mathrm{C} 6\end{array}$ & $\begin{array}{l}\text { E2, E3 } \\
\text { E4, E5 }\end{array}$ & $\mathrm{C} 1, \mathrm{C} 6$ & $\begin{array}{c}\text { E1, E4 } \\
\text { E5 }\end{array}$ & $\begin{array}{l}\mathrm{C} 1, \mathrm{C} 2 \\
\mathrm{C} 3, \mathrm{C} 6\end{array}$ & $\begin{array}{c}\text { E1, E2 } \\
\text { E3, E5 } \\
\text { E7 }\end{array}$ & $\begin{array}{l}\mathrm{C} 2, \mathrm{C} 3 \\
\mathrm{C} 5, \mathrm{C} 6\end{array}$ & $\begin{array}{c}\text { E1, E3 } \\
\text { E5, E6 } \\
\text { E7 }\end{array}$ & $\begin{array}{c}\mathrm{C} 2, \mathrm{C} 3 \\
\mathrm{C} 6\end{array}$ & $\begin{array}{c}\mathrm{E} 1, \mathrm{E} 2 \\
\mathrm{E} 4\end{array}$ \\
\hline
\end{tabular}

TABLE II shows the statistical result of expert questionnaire. The distribution of resources $\mathrm{C}$ and $\mathrm{E}$ represents the firm-level requirements in each segment for developing different specialization strategy by distinct innovation type. The managerial explanation means that the service platform enterprises must syndicate the essential value activities (C) and externalities (E) illustrated in TABLE II for achieving the specific specialization goal in the corresponding segments. Not only does this analysis reveal the platform strategies of services enterprises, but also it offers the linkage elements between the firm-level innovation types and the specialization directions

\section{EMPIRICAL RESULTS}

This research selects the Telematics service industry in Taiwan as the research objective of empirical studies. This industry is the good case to demonstrate the service platform model for specialization strategies due to the characteristics of customer-centric leadership and knowledge intensive competition, and the industrial driven forces of the diversity of highly segmented markets, systems and platform services, and technology-enabled new markets.

\section{A. Introduction of Telematics Service Industry}

The industrial term "Telematics" is originally the combination of two systems of "Telecommunications" and "Informatics". The scope of industry includes the hardware, software, and the content provider of automobile communication, wireless internet, database, information integration, and entertainment systems. It is belonged to the part of automobile electronics industry, and involves the system 
products with the functions of safety \& security, entertainment, e-commerce, driving and life information services.

This research adopts the industrial value chain and fishbone diagram, to define the segment of Telematics service industry, as illustrated in Fig. 3. and 4. It shows that the Telematics service provider (TSP) industry plays the role of interface between the traditional automobile corporations and content provider, telecommunications institution, hardware and software provider.

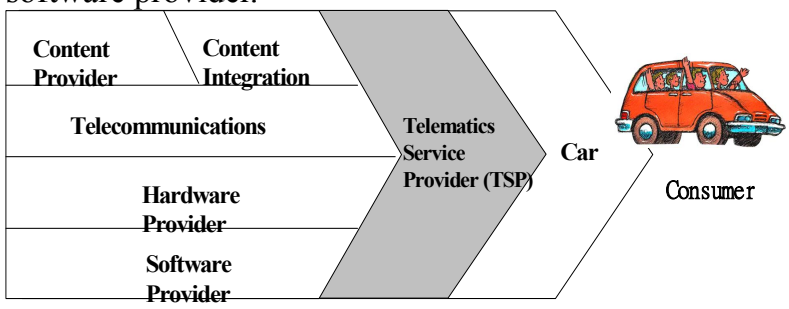

Fig. 3. Value chain of Telematics industry

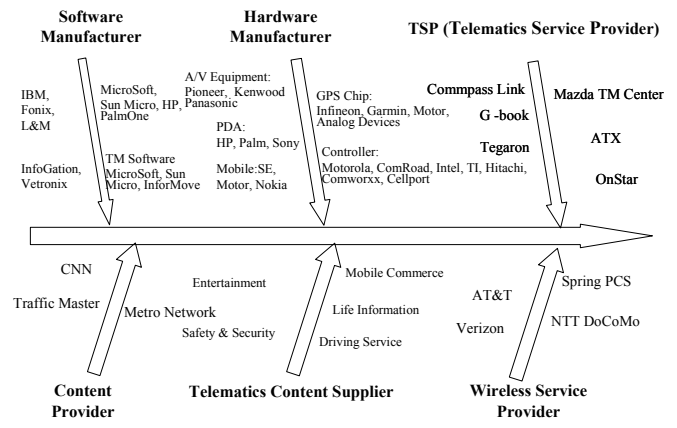

Fig. 4. Fishbone diagram of Telematics industry

\section{B. Results of Empirical Analysis}

This research selects 132 related experts in Taiwan's automobile and auto-electronics industry including managers, engineers, market analyzers, and professors, to investigate the present and future strengths of six value activities (C) and seven externalities (E) in Telematics service enterprises, thereby determining the resource gap of these requirements in these 48 specialization segments. The 52 effective questionnaires were finished and the response rate is $39.3 \%$ from Feb. to May. in 2007.

TABLE III presents the results of questionnaire statistics, and the numbers in each segment means the resource gap for $\mathrm{C}$ and $\mathrm{E}$ between present and future Telematics service enterprises. This gap shows that the less the number is, the easier the specialization goals could be achieved. Thus, the results of TABLE III reveals that the optimal specialization strategies of Taiwan's Telematics service industry is the marketing brand \& channels specialization based on market innovation, and the network \& platform operations specialization based on structural innovation. The resource gaps for $\mathrm{C}$ and $\mathrm{E}$ in these two positioning segments are obviously easier to be achieved.

TABLE III

SPECIALIZATION ANALYTICAL RESULTS OF TELEMATICS SERVICE INDUSTRY

\begin{tabular}{|c|c|c|c|c|c|c|c|c|}
\hline Innovation & $\begin{array}{c}\text { R\&D \& } \\
\text { Product } \\
\text { Innovation }\end{array}$ & $\begin{array}{l}\text { Marketing } \\
\text { Brand \& } \\
\text { Channels }\end{array}$ & $\begin{array}{c}\text { Market } \\
\text { Diversity }\end{array}$ & $\begin{array}{c}\text { System } \\
\text { Design \& } \\
\text { Manufacturing }\end{array}$ & $\begin{array}{l}\text { Regional } \\
\text { Clustering }\end{array}$ & $\begin{array}{l}\text { Technology } \\
\text { Innovation }\end{array}$ & $\begin{array}{c}\text { Financial } \\
\text { Strengths \& } \\
\text { Investment }\end{array}$ & $\begin{array}{l}\text { Network \& } \\
\text { Platform } \\
\text { Operations }\end{array}$ \\
\hline \multicolumn{9}{|l|}{$\begin{array}{l}\text { Product } \\
\text { innovation }\end{array}$} \\
\hline \multicolumn{9}{|l|}{$\begin{array}{l}\text { Process } \\
\text { innovation }\end{array}$} \\
\hline \multicolumn{9}{|l|}{$\begin{array}{l}\text { Organizational } \\
\text { innovation }\end{array}$} \\
\hline \multicolumn{9}{|l|}{$\begin{array}{l}\text { Structural } \\
\text { innovation }\end{array}$} \\
\hline \multicolumn{9}{|l|}{$\begin{array}{l}\text { Market } \\
\text { innovation }\end{array}$} \\
\hline
\end{tabular}


Refer to the analysis of TABLE II, the results also depicts that the value activities of validation of testing (C2), delivery (C4) and supporting activities (C6), and the externalities of production (E4) and servicing (E5) must be strengthened while developing the marketing brand \& channels specialization by market innovation. In the meanwhile, the value activities of marketing (C3), delivery (C4), after service (C5) and supporting activities (C6), and the externalities of complementary assets suppliers (E4) and servicing (E5) must also be emphasized while developing the network \& platform operations specialization by structural innovation

\section{CONCLUSIONS}

This research adopts the concept of IIS platform model, connecting firm's core competence, value activities, and externalities, based on pre-determined specialization strategy, to construct a specialization analytical matrix. Eight specialization strategies, including $R \& D$ and product innovation, marketing brand and channels, market diversity, system design and manufacturing, regional clustering, technology innovation \& leadership, financial strengths and investment portfolio, network and platform operations specialization, can be devised and selected for the service enterprises by the operation of this model. Results of the empirical study reveal that the optimal specialization strategies of Taiwan's Telematics service industry is the marketing brand \& channels specialization based on market innovation, and the network \& platform operations specialization based on structural innovation. The research also indicates that the value activities of delivery and supporting activities for the platform must be emphasized for developing the above mentioned strategic direction, and the externalities of service is also essential for specialization of Telematics service industry.

\section{REFERENCES}

[1] P. B. Evans, and T. S. Wurster, "Strategy and the New Economics of Information", In D. Tabscott. (Eds.), Creating Value in the Network Economy, Harvard Business School Press, Boston, 1999. pp.13-34.

[2] H. C. Chen, An Integrated Value-Creation Process for Innovation Intensive Industries, Unpublished Ph.D. Dissertation, Institute of Management of Technology, National Chiao Tung University, 2006.

[3] C. Christensen, and M. Raynor, The Innovator's Solution: Creating and Sustaining Successful Growth, Harvard Business School Press, 2003.
[4] A. J. Slywotzky, Value Migration: How to Think Several Moves ahead of the Competition, Corporate Decisions, 1996.

[5] B. Arthur, "Increasing Returns and the New World of Business". Harvard Business Review. July-August, 1996, pp.100-109.

[6] C. Shapiro, and H. Varian, Information Rules: a Strategic Guide to the Network Economy, Harvard Business School Press, 1999.

[7] H. C. Chen, and J. Z. Shyu, "Intensive Service as Actors of Platform Strategy Adapted to Emerging Industry Development", Portland International Conference on Management of Engineering \& Technology, Seoul, Korea. 2004.

[8] OECD, Science, Technology and Industry Scoreboard: Benchmarking Knowledge-based Economies, OECD, Paris. 1999.

[9] P. Hertog, and R. Bildebeek, The New Knowledge Infrastructure: The Role of Technology-Based Knowledge-Intensive Business in National Innovation System, Continuum, London, 1998.

[10] E. Muller, and A. Zenker, "Business Services as Actors of Knowledge Transformation: the Role of KIBS in Regional and National Innovation Systems", Research Policy, 30 (9), 2001. pp.1501-1516.

[11] H. C. Browning, and J. Singelmann, "The Emergence of a Service Socity”, Strategic Management Journal, Vol.15, 1975, pp.167-183.

[12] I. Miles, Knowledge-Intensive Business Services: Users, Carriers and Sources of Innovation, Information Market and Exploitation of Research, Directorate General for Telecommunications, Information Market and Exploitation of Research, Commission of the European Communities. 1995.

[13] D. E. Kash, and R. W. Rycoft, "Patterns of Innovating Complex Technologies: A Framework for Adaptive Network Strategies", Research Policy, Vol.29, 2000, pp.819-831.

[14] C. K. Prahalad, and G. Hamel, "The Core Competences of the Corporation", Harvard Business Review, May-June, 1990. pp.79-91.

[15] J. Hauknes, and K. Hales, Service in Innovation - Innovation in Services, SI4S Synthesis Paper. 1998.

[16] I. Alam, and C. Perry, "A Customer-oriented New Service Development Process", The Journal of Services Marketing, $16,6,2002$, pp.525.

[17] J. A. Fitzsimmons, and M. J. Fitzsimmons, Service Management for Competitive Advantage, McGraw-Hill, New York, 1994.

[18] D. L. Kellogg, and W. Nie, "A Framework for Strategic Service Management", Journal of Operations Management, 13 (4), 1995. pp.323-337. 